\title{
New Higher Education Policy: A Comprehensive Model
}

\author{
R. P. Yadav \\ Associate Professor and Head, Department of Physics, Govt. P.G. College, Bisalpur, Pilibhit- 262201
}

\begin{abstract}
To eradicate complete unemployment from India, we have to adopt job oriented education. In this paper, comprehensive model of Higher Education is suggested.
\end{abstract}

Keywords: Higher Education, Unemployment, skill development, model, social work, morel education

\section{Aim and Objectives of Education}

The purpose of education is the all round development of personality. But the present day education is neither imparting true knowledge of life and nor improving the talent of a student by which one can achieve laurels in the field one is interested. Students, teachers, guardians and all the other stakeholders are blaming the existing system of higher education. Therefore, a new model of higher education for India is suggested in this paper. It is suggested that after passing $12^{\text {th }}$ student ${ }^{\text {(Excluding IITS /AIIMS /IIMs/TTI ) }}$ has to opt one of the four streams given below.

\section{1st Stream}

Subjects to be opt

ONE from 283 diploma of UPSDM (i.e. Diploma in Electrical/Electronics/mechanical/mobile repair/Inverter maintenance/mass communication/C.A/C.S/dairy industry/farming/soft/hardware/health Sci.)

+ Communicative English + Basics of Computer Sci.

+Foundation of B.A./B.Sc./B.Com.(For self- employment)

\section{$2^{\text {nd }}$ Stream}

Subjects to be opt

ONE from 283 diploma of UPSDM

+Communicative English + Basics of Computer Sci.

+ Foundation of B.A./B.Sc./B.Com. + Physical Education

For Force services (i.e. police, military BSF etc)

\section{$3^{\text {rd }}$ Stream}

Subjects to be opt

ONE from 283 diploma of UPSDM

+Communicative English + Basics of Computer Sci.

+ Foundation of B.A./B.Sc./B.Com.

For civil services (state level/centre level)

\section{$4^{\text {th }}$ Stream}

Subjects to be opt

ONE from 283 diploma of UPSDM

+Communicative English + Advance level Computer Sci. +

Advance level B.A./B.Sc./B.Com.

For Post Graduation /MBA/MCA/ Degree for

teaching/Ph.D./ NET/ Scientists.

\section{Conclusions}

1) 1 st Stream is for the students who are interested in their own business/ self- employment.

2) $2^{\text {nd }}$ Stream is suitable for the physically good students who are interested to join Force services (i.e. police, military, BSF etc.)

3) $3^{\text {rd }}$ Stream is recommended for the students who are interested in civil services (state level/centre level)

4) $4^{\text {th }}$ Stream is only for the students who are interested in Post Graduation for MBA/MCA/Degree for teaching/Ph.D./NET/Scientist.

It is further suggested that social work along with morel education should be mandatory in all the streams for six months duration in the beginning of the $1^{\text {st }}$ year. It will help in making good citizen /nation having adequate employment.

\section{Limitation}

Since every student is professionally skilled in first year of his graduation, therefore, it may be assumed that unemployment problem will be no more in India.

The main point of discussion in this model is how to bifurcate students in streams.

\section{References}

[1] www.upsdm.org

[2] www.ugc.ac.in

[3] www.mhrd.gon.in 